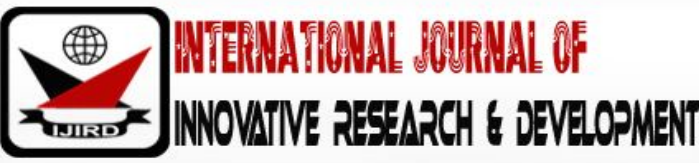

ISSN 2278 - 0211 (Online)

\section{Effect of Packaging Materials and Storage Environment on Fungal Growth and Shelf Life of Local Bread (Madiga) in Bayelsa State, Nigeria}

Anumudu, Christian K.
Lecturer, Department of Microbiology, Federal University Otuoke, Nigeria
Okolo, Chioke A.
Anumudu, Irene C.
Lecturer, Department of Food Science and Technology, Nnamdi Azikiwe University Awka, Nigeria
Postgraduate Researcher, Department of Public Health, Federal University of Technology Owerri, Nigeria

\begin{abstract}
:
Madiga is a local bread produced from composite wheat flour. It is one of the local bakery products that has become an important staple food that is consumed among the people of the Niger Delta region of Nigeria because of its sweet taste and low cost. This study focused on identifying the fungi associated with the spoilage of madiga and the effect of packaging material and storage temperature on fungi growth and shelf life of madiga. Six (6) samples of madiga bread were obtained from a local bakery and packaged in aluminum foil, cling film and polyethylene bags. These were stored at room temperature and refrigeration temperature. Several fungi were isolated including Mucorsp., Aspergillus sp., Fusarium sp., Penicillium sp. and Rhizopus sp. using the spread plate method. Fungal count ranged from $1.8 \times 10^{4} \mathrm{CFU} / \mathrm{g}$ to 8.5 x $10^{8} \mathrm{CFU} / \mathrm{g}$, with Mucorsp. recording the highest occurrence at $40 \%$ while Fusarium sp. recorded the least occurrence at $6.6 \%$. After six days, of the packaging material used for the storage of madiga bread, the samples packaged in cling film and stored at room temperature showed the lowest fungal count at $1.4 \times 10^{7} \mathrm{CFU} / \mathrm{g}$, thus suggesting that this is best material and temperature for the storage of madiga bread.
\end{abstract}

Keywords: Bread (madiga), Fungi, Packaging material, shelf-life, storage environment

\section{Introduction}

Bread is a staple food prepared using dough of flour of different natures (Olaoye et al., 2006) including rye, barley, maize, and other grains. It may be leavened or unleavened and can contain a variety of ingredients including salt, sugar, milk, honey, spices, fruits, nuts etc. (Davidson, 2014). In developing countries, composite flour is being employed for the production of bread and other bakery products, making use of locally grown grains, mainly because the use of imported wheat flour is expensive (Hugo etal.,2003). Studies have shown the efficacy of using composite flours from locally grown crops and high protein seeds for the production of bread and other bakery products, thereby decreasing the demand for imported wheat and producing protein enriched bread (Giami et al.,2004). Madiga is a local bread product usually consumed by the people of the Niger Delta region of Nigeria. It is one of the famous local bakery product that have become an important staple food among the people of the Niger Delta region of Nigeria. It is produce fromcomposite wheat flour and it is a delicacy amongst the people of the Niger Delta because of its sweet taste and low cost.

Bread loaves fresh out of the oven are free of molds or mold spores due to their thermal inactivation during the baking process (Ponte and Tsen, 1978) bread becomes contaminated after baking, from the mold spores present in the atmosphere surrounding loaves during cooling, slicing, packaging and storage. Most common source of microbial spoilage in bread is due to mold growth. Previous studies by Banwart (2004), have indicated that bread mold such as Mucorsp. and Rhizopussp. are found to grow first during bread spoilage. This is followed by other fungi including; Aspergillus sp.Penicilliumsp. and Fusariumsp. Among these,Penicillium sp. is the most common althoughAspergillussp. may be of greater significance in tropical countries (Legan, 1993) due to their ability to cause a variety of human illnesses. Mold are capable of causing various diseases in human and animals, this is due to the production of mycotoxins in the foods they grow on (Jay, 2000). An example is Aspergillus sp. which can cause a variety of ailments including neoplasms, growth in the lungs and 
kidneys,allergic bronchopulmonary aspergillosis (BPA). Furthermore, toxic reactions to mycotoxins such as aflatoxin which are carcinogenic may induce hepatocellular carcinoma or liver cancer. (Collier et al., 1998).

With respect to the shelf life of bread and spoilage by fungi, packaging materials and the storage environment play a significant role. Bread can be stored at any temperature ranging from cool to hot once baked. It can subsequently be toasted before consumption.In common with all microorganism, fungi are profoundly affected by physical and physiochemical factor such as temperature, $\mathrm{pH}$, light, moist condition etc. Different authors such as Dzomeku et al., (2012) have investigated the effect of packaging material such as aluminum foil, news print and sterile polyethylene bag on the shelf life of different brands of bread. This work is focused on the determination of fungi responsible for post-processing contamination and spoilage of local bread (madiga) and the effect of storage temperature and packaging material on the fungal load and shelf life of the local bread.

\section{Methodology}

Six (6) samples of madiga bread all from the same batch was purchased from a local bakery in Yenegoa, Bayelsa State. The samples were transported to the laboratory for analysis. Two samples were packaged using aluminum foil, another two using cling film and the last two was packaged in polyethylene bags. One of the sample from each of the packaging material was stored in the refrigerator maintained at $4^{\circ} \mathrm{C}$ while the other halves were stored at room temperature $\left(25^{\circ} \mathrm{C}\right)$ on the laboratory bench. All the glassware utilized was sterilized in a hot air oven maintained at $160^{\circ} \mathrm{C}$ for one hour, while other materials were sterilized in an autoclave maintained at $121^{\circ} \mathrm{C}$ for 15 minutes. Ten-fold serial dilution was undertaken on each of the samples using sterile distilled water up to $10^{-4}$. Aliquots were taken from the dilutions within one minute to prevent the sedimentation of the fungal spores, as described by Beuchat, (1992). $0.1 \mathrm{ml}$ of the aliquot was transferred to the surface of prepared and solidified potato dextrose agar (PDA) media supplemented with tetracycline antibiotics to prevent the growth of bacterial contaminants. The sample was spread over the surface of the PDA using sterile bent glass rod. The plates were incubated at $25^{\circ} \mathrm{C}$ for $4-5$ days in the upright position. After incubation, the fungal count was recorded using a colony counter. The different colonial morphologies obtained was recorded by visual observation before being sub-cultured to a new PDA plate. After subculturing, a small portion each of the sub-cultured colony was cut using a sterile scalpel and placed on a sterile glass slide using a sterile forcep. This was covered with a cover slip and placed in a petridish containing moistened cotton wool swabs and covered. This was allowed to stand for 3 days at $25^{\circ} \mathrm{C}$. Afterwards, the cover slips were removed with a forcep and placed on glass slides containing lactophenol-cotton blue stain. This was observed under the microscope to identify the shape, structure of conidia, pigmentation etc. This same procedure was undertaken for all the samples and repeated on days 1, 3 and 6 of storage.

\section{Results and Discussion}

After incubation for six (6) days, the following fungal load was observed for the different samples

\begin{tabular}{|c|c|c|c|}
\hline Sample & Day 1 & Day 3 & Day 6 \\
\hline Aluminum foil (Room temp) & $1.8 \times 10^{4} \mathrm{Cfu} / \mathrm{g}$ & $1.4 \times 10^{6} \mathrm{Cfu} / \mathrm{g}$ & $1.5 \times 10^{8} \mathrm{Cfu} / \mathrm{g}$ \\
\hline Aluminum foil (Refrigerator) & $5.8 \times 10^{5} \mathrm{Cfu} / \mathrm{g}$ & $6.2 \times 10^{6} \mathrm{Cfu} / \mathrm{g}$ & $8.5 \times 10^{8} \mathrm{Cfu} / \mathrm{g}$ \\
\hline Cling film (Room temp) & $3.3 \times 10^{5} \mathrm{Cfu} / \mathrm{g}$ & $8.1 \times 10^{5} \mathrm{Cfu} / \mathrm{g}$ & $1.4 \times 10^{7} \mathrm{Cfu} / \mathrm{g}$ \\
\hline Cling film (Refrigerator) & $3.8 \times 10^{5} \mathrm{Cfu} / \mathrm{g}$ & $5.5 \times 10^{6} \mathrm{Cfu} / \mathrm{g}$ & $9.0 \times 10^{7} \mathrm{Cfu} / \mathrm{g}$ \\
\hline Polyethylene (Room temp) & $6.2 \times 10^{5} \mathrm{Cfu} / \mathrm{g}$ & $7.5 \times 10^{5} \mathrm{Cfu} / \mathrm{g}$ & $1.1 \times 10^{8} \mathrm{Cfu} / \mathrm{g}$ \\
\hline Polyethylene (Refrigerator) & $7.0 \times 10^{5} \mathrm{Cfu} / \mathrm{g}$ & $9.5 \times 10^{5} \mathrm{Cfu} / \mathrm{g}$ & $1.3 \times 10^{8} \mathrm{Cfu} / \mathrm{g}$ \\
\hline
\end{tabular}

Table 1: Fungal Load of Samples

The result shows that after six days of storage, the samples packaged with cling film had the lowest fungal count of 1.4 $\mathrm{x} 10^{7} \mathrm{Cfu} / \mathrm{g}$, followed by polyethylene bag at $1.1 \times 10^{8} \mathrm{Cfu} / \mathrm{g}$. irrespective of the packaging material, all samples stored at room temperature had lower fungal loads than their counterparts stored at refrigeration temperature, thus suggesting that the best method of storing bread is at room temperature. Furthermore, there is a progressive increase as expected in the fungal load of the local bread with an increase in the storage time. This corresponds to the findings of Ravimannan et al., (2016).

All fungi isolated was identified based on their colonial and cultural morphologies as described by Harrigan and McCane, (1976). The following characteristics was recorded for isolated fungi 


\begin{tabular}{|c|c|c|}
\hline Fungal Isolate & Cultural Characteristics & Microscopic Characteristics \\
\hline Aspergillus sp. & $\begin{array}{c}\text { Yellowish-green and green } \\
\text { colonies with clear margins }\end{array}$ & $\begin{array}{c}\text { Conidia occur in chains with the conidiophoreshaving } \\
\text { club shaped vesicles at the top. }\end{array}$ \\
\hline Mucor sp. & $\begin{array}{c}\text { Large white colonies which } \\
\text { turns to black after three } \\
\text { days }\end{array}$ & $\begin{array}{c}\text { Sporangiospores are present inside a spherical } \\
\text { sporangium which is swollen at the tip. }\end{array}$ \\
\hline Rhizopus sp. & $\begin{array}{c}\text { White raised colonies with a } \\
\text { cottony mycelium which } \\
\text { turns brownish to black } \\
\text { after sporulation. }\end{array}$ & $\begin{array}{c}\text { Sporangiospores are producedinside a spherical } \\
\text { sporangium. Columella is present on the topof the } \\
\text { sporangiospore. Root-likerhizoids are found. }\end{array}$ \\
\hline Penicillium sp. & $\begin{array}{c}\text { Green fast-growing colonies } \\
\text { with a dense conidia }\end{array}$ & Branched conidiophores with chains of conidia \\
appearing like a brush.
\end{tabular}

Table 2: Cultural and Microscopic Morphologies of Identified Fungi

The fungi isolates obtained corresponds to the typical genera associated with bread spoilage as reported by Ravimannan et al., (2016).The following five fungi genera were isolated from the samples with the highest occurrence recorded for Mucorsp. at 40\% while the least occurrence was recorded by Fusarium sp. at 6.66\%, occurring in only two (2) samples on different days of analysis.

\begin{tabular}{|c|c|c|}
\hline Fungal Isolate & Frequency of Occurrence in Samples & \% Frequency \\
\hline Fusarium sp. & 2 & 6.66 \\
\hline Penicillium sp. & 3 & 10 \\
\hline Aspergillus sp. & 5 & 16.6 \\
\hline Mucor sp. & 12 & 40 \\
\hline Rhizopus sp. & 8 & 26.6 \\
\hline & Total=30 & \\
\hline
\end{tabular}

Table 3: Frequency of Occurrence of Different Fungi

\begin{tabular}{|c|c|}
\hline Sample & Fungi \\
\hline Aluminum foil (Room temp) & Penicilliumsp., Aspergillus sp., Mucor sp., Rhizopus sp. \\
\hline $\begin{array}{c}\text { Aluminum foil } \\
\text { (Refrigerator) }\end{array}$ & Fusarium sp., Aspergillussp., Mucorsp., Penicillium sp. \\
\hline Cling film (Room temp) & Mucorsp. \\
\hline Cling film (Refrigerator) & Mucorsp., Aspergillussp. \\
\hline Polyethylene (Room temp) & Penicillium sp., Mucorsp. \\
\hline Polyethylene (Refrigerator) & Aspergillus sp., Mucor sp., Fusariumsp. \\
\hline
\end{tabular}

Table 4: Fungi Associated with Each Sample

The result above shows that the best packaging material for the storage of local bread is cling film, placed at room temperature. This may be associated with the exclusion of air by the cling film which attaches strongly to the bread. Overall, this study has shown that fungi growth increases in local bread with increase in the storage period and the major spoilage organism associated with madiga bread is Mucorsp. To elongate the shelve life of madiga, the product should be wrapped in cling film and stored at normal room temperature of about $25^{\circ} \mathrm{C}$.

\section{References}

i. Beuchat, L.R. (1992). Media for detecting and enumerating yeasts and molds. International Journal of Food Microbiology. 17, 145-148.

ii. Banwart, G. J (2004).Basic Food microbiology. A Westport Publication. Pp. 505-544.

iii. Collier L., Balows, A. and Sussman, M.(1998)Topley and Wilson's microbiology and microbial infection, 9thed, vol. 4 Arnold, London, Sydney, Auckland, New York.

iv. Davidson, A. (2014). The Oxford companion to food. $3^{\text {rd }}$ Ed. Oxford University Press, London. 
v. Domeku, M.B., Timuub, B.M., Akweiba, P., Addo, J.K. and Appiah-Kubi, Z. (2012). Assessing the proximate composition and shelf-life of different brands of bread on the market in Ghana. Annals. Food Science and Technology. 13(1).29-36.

vi. Giami, G.Y., Amasisi, T. andEkiyor, G. (2004). Comparison of bread making properties of composite flour from kernels of roasted and boiled African bread fruit (Treculia Africana) seed.J. Mat. Res., 1:16-25.

vii. Harrigan W.F. and MC-Cane, M.B. (1976). Laboratory methods in food and dairy microbiology. Academic Press. New York.

viii. Hugo. L.F., Rooney, L.W, and Taylor, J.R.N. (2003). Fermented sorghum as a functional ingredient in composite breads cereal.Chem. 80:495-499.

ix. Jay, M. S. (2000). Modern food microbiology, sixth ed. Aspen publishers, Mary Land.

x. Legan, J.D. (1993). Mold spoilage of bread: The problem and some solutions. International Journal of biodeterioration and biodegradation.32:33-53.

xi. Olaoye, O.A., Onilude,A.A. and Idowu,O.A. (2006). Quality characteristics of bread produced fromcomposite flours of wheat, plantain and soybeans.Africa.J. Biotechnol., 11: 1102-1106.

xii. Ponte, J.G and Tsen, C.C. (1978). Bakery products In: Food and Beverage mycology (ed. L.R. Beuchat). AW publishing Co, West Port, CT. pp 191 -223.

xiii. Ravimannan, N.,Sevvel, P.,and Saarutharshan, S.(2016). Study on fungi associatedwith spoilage of bread. International Journal of Advanced Research in Biological Science. 3(4): 165-167 